Images in...

\title{
Breast 'rupture' due to a phyllodes tumour
}

S M Wijeyaratne,

Department of Surgery, University of Colombo, Colombo, Sri Lanka

Correspondence to S M Wijeyaratne, mandika59@hotmail.com

\section{DESCRIPTION}

Figure 1 shows a fungating but no-cancerous breast tumour. Rapid growth of the non-malignant stromal tumour described as a phyllodes tumour involved most of the breast and caused breast 'rupture' from pressure necrosis of the overlying skin.

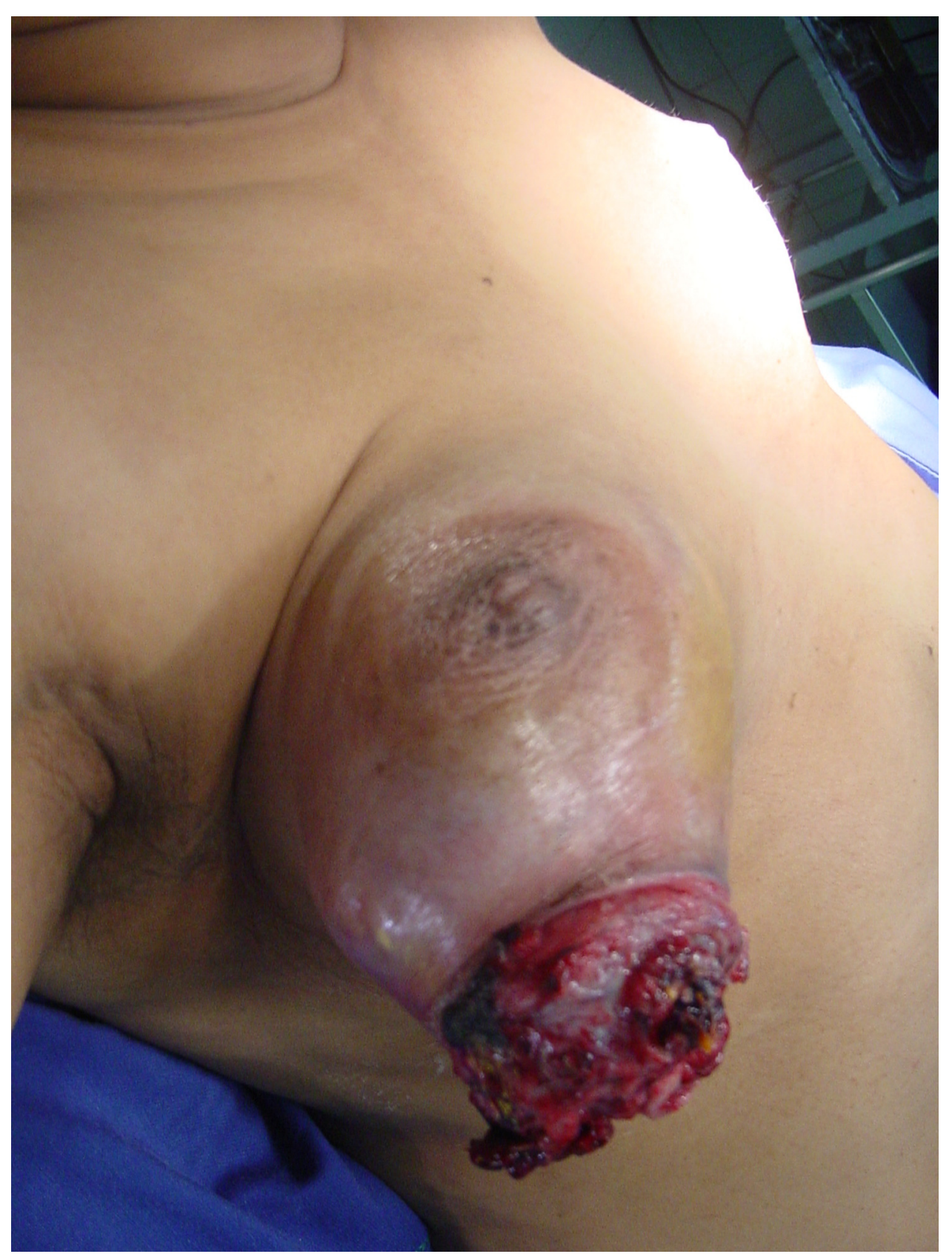

Figure 1 The right breast showing a large fleshy tumour protruding from the lower outer quadrant with most of the remaining breast also containing tumour. The surrounding skin although bluish is not oedematous. 


\section{BMJ Case Reports}

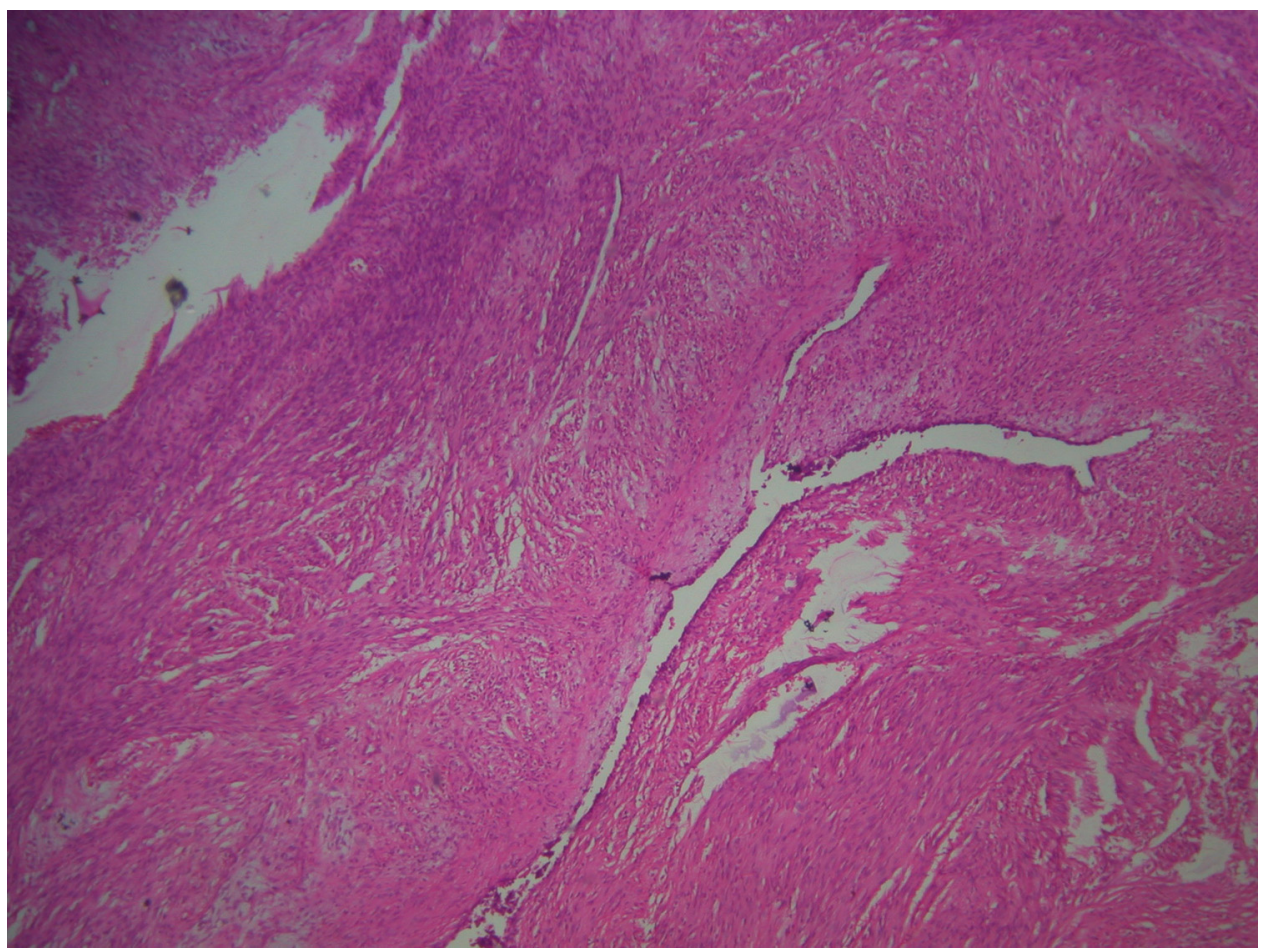

Figure 2 Histology with haematoxylin eosin stains revealed leaf-like architecture, long clefts with marked stromal overgrowth and hypercellularity characteristic of a phyllodes tumour.

The 48-year-old woman had been institutionalised and poorly cared for because of schizophrenia. A small breast lump had been present over many years and had started to enlarge in the last 3 months. The late presentation was due to social withdrawal, paranoia and refusal to seek treatment.

She was single and nulliparous but without a family history of breast cancer. Fungating tumours of the breast are commonly attributed to invasive duct carcinoma. An everted ulcer edge and oedema of the surrounding skin are characteristic. Nevertheless, images presented show a tumour without skin oedema, fixity or attachment suggestive of malignant infiltration. There was no axillary lymphadenopathy or distant metastases. Core biopsy revealed leaf-like architecture with marked stromal overgrowth and hypercellularity suggestive of a borderline phyllodes tumour (figure 2). Clonal studies have confirmed that fibroadenomata could progress to phyllodes tumours. ${ }^{1}$ These tumours tend to be locally invasive, but only rarely metastasise to distant sites. Wide local excision alone is recommended to prevent local recurrence. ${ }^{2} 3$

Aggressive pharmacotherapy and counselling enabled optimum treatment in this instance. Considering the large size of the tumour she underwent simple mastectomy with clear margins and remains disease-free 4 years later. She now lives with her sister and complies with regular followup medical care.
Learning point

- Rarely, long standing fibroadenomata transform in to locally aggressive stromal tumours known as phyllodes tumours and proceed to ulcerate without skin infiltration - that is, nodules, peau d'orange.

- Poorly managed psychiatric disorders may lead to late presentation and delayed treatment.

- Enucleation is insufficient and wide local excision is recommended to prevent local recurrence.

Competing interests None.

Patient consent Obtained.

\section{REFERENCES}

1. Noguchi S, Yokouchi H, Aihora T, et al. Progression of fibroadenoma to phylloides tumour demonstrated by clonal analysis. Cancer 1995;76:1779-85.

2. Pezner RD, Schultheiss TE, Paz IB. Malignant phyllodes tumor of the breast: local control rates with surgery alone. Int J Radiat Oncol Biol Phys 2008; 71:710-13.

3. Haberer S, Laé M, Seegers V, et al. Management of malignant phyllodes tumors of the breast: the experience of the Institut Curie. Cancer Radiother 2009;13:305-12. 


\section{BMJ Case Reports}

This pdf has been created automatically from the final edited text and images.

Copyright 2010 BMJ Publishing Group. All rights reserved. For permission to reuse any of this content visit

http://group.bmj.com/group/rights-licensing/permissions.

BMJ Case Report Fellows may re-use this article for personal use and teaching without any further permission.

Please cite this article as follows (you will need to access the article online to obtain the date of publication).

Wijeyaratne SM. Breast 'rupture' due to a phyllodes tumour. BMJ Case Reports 2010;10.1136/bcr.03.2010.2790, date of publication

Become a Fellow of BMJ Case Reports today and you can:

- Submit as many cases as you like

Enjoy fast sympathetic peer review and rapid publication of accepted articles

Access all the published articles

Re-use any of the published material for personal use and teaching without further permission

For information on Institutional Fellowships contact consortiasales@bmjgroup.com

Visit casereports.bmj.com for more articles like this and to become a Fellow 